Article

\title{
Life Cycle Assessment of Households in Santiago, Chile: Environmental Hotspots and Policy Analysis
}

\author{
Camila López-Eccher ${ }^{1}$, Elizabeth Garrido-Ramírez ${ }^{2}$, Iván Franchi-Arzola ${ }^{2} \mathbb{D}$ and Edmundo Muñoz ${ }^{2, *(\mathbb{D})}$ \\ 1 School of Environmental Sciences and Sustainability, Universidad Andres Bello, Santiago 8370251, Chile; \\ camilaa.lopez@uandresbello.edu \\ 2 Center for Sustainability Research, Universidad Andrés Bello, Santiago 8370251, Chile; \\ elizabeth.garrido@unab.cl (E.G.-R.); ivan.franchi@unab.cl (I.F.-A.) \\ * Correspondence: edmundo.munoz@unab.cl; Tel.: +56-2-26618370
}

Citation: López-Eccher, C.;

Garrido-Ramírez, E.; Franchi-Arzola, I.; Muñoz, E. Life Cycle Assessment of Households in Santiago, Chile: Environmental Hotspots and Policy Analysis. Sustainability 2021, 13, 2525 https://doi.org/10.3390/su13052525

Academic Editor: Bhavik Bakshi

Received: 5 February 2021

Accepted: 23 February 2021

Published: 26 February 2021

Publisher's Note: MDPI stays neutral with regard to jurisdictional claims in published maps and institutional affiliations.

Copyright: (c) 2021 by the authors. Licensee MDPI, Basel, Switzerland. This article is an open access article distributed under the terms and conditions of the Creative Commons Attribution (CC BY) license (https:// creativecommons.org/licenses/by/ $4.0 /)$.

\begin{abstract}
The aim of this study is to assess the environmental impacts of household life cycles in Santiago, Chile, by household income level. The assessment considered scenarios associated with environmental policies. The life cycle assessment was cradle-to-grave, and the functional unit considered all the materials and energy required to meet an inhabitant's needs for one year (1 inh/year). Using SimaPro 9.1 software, the Recipe Midpoint (H) methodology was used. The impact categories selected were global warming, fine particulate matter formation, terrestrial acidification, freshwater eutrophication, freshwater ecotoxicity, mineral resource scarcity, and fossil resource scarcity. The inventory was carried out through the application of 300 household surveys and secondary information. The main environmental sources of households were determined to be food consumption, transport, and electricity. Food consumption is the main source, responsible for $33 \%$ of the environmental impacts on global warming, $69 \%$ on terrestrial acidification, and $29 \%$ on freshwater eutrophication. The second most crucial environmental hotspot is private transport, whose contribution to environmental impact increases as household income rises, while public transport impact increases in the opposite direction. In this sense, both positive and negative environmental effects can be generated by policies. Therefore, life-cycle environmental impacts, the synergy between policies, and households' socio-economic characteristics must be considered in public policy planning and consumer decisions.
\end{abstract}

Keywords: LCA; city metabolism; environmental management

\section{Introduction}

Urban areas are considered the home of prosperity and development and large consumers of resources, which generate pollution, unsustainable growth, and social inequality [1]. Urban areas are responsible for $75 \%$ of the planet's resource and energy consumption and $80 \%$ of global $\mathrm{CO}_{2}$ emissions [2]. This situation will worsen, considering that today around $50 \%$ of all inhabitants live in cities [3], and estimates indicate that this number will reach $68 \%$ by 2050 [4]. Thus, there is an increasing focus on consumption as an essential driver of social metabolism [5]. It has also shifted the focus to consider the requirements associated with the final sector demand, including that of households [6]. Beginning in the 1990s, older approaches evolved to take into account consumption [7], and new approaches appeared, such as integrated production or sustainable consumption and production policies [8,9], with particular focus on household consumption [7].

A household is defined as a group of persons who share the same living accommodation, pool some, or all, of their income and wealth, and consume certain types of goods and services collectively [6,7]. Households are significant drivers of the economy. Their consumption behavior triggers many economic activities along the supply chain of each product and service, which subsequently involves using resources and the release of 
emissions [10]. For this reason, the household might be regarded as ultimately responsible for environmental impacts occurring over the life cycle of products and services [10].

Many studies have focused on the resource consumption and environmental impacts of households. According to Matuštík and Kočí [11], personal consumption is among the most significant contributors affecting the global environment. Newton and Meyer [12] studied urban resource consumption such as water, energy, domestic appliances, and transport before concluding that it is more affected by contextual factors (household, dwelling and location) than individual ones (structural and attitudinal). Similarly, Froemelt et al. [10] assessed household consumption behavior. However, they focused their attention on assessing environmental impacts, proposing new approaches to determine their variability. The application of this approach demonstrates that within similar socioeconomic household types, different archetypes can be found. The proposed approach could lead to a better understanding of consumption patterns and the future support of environmental policymakers targeting specific consumer groups. In this sense, understanding the variability of consumption patterns and associated environmental impacts is required to devise targeted environmental policies [10]. Kalbar et al. [13] analyzed how urban lifestyles impact the environment. They applied a life cycle assessment approach coupled with personal metabolism, which determined that demographic parameters such as income level and respondent age strongly influence environmental impacts. Diet choices, private car use, and household size also significantly influence consumption-related environmental impacts.

Impacts associated with household consumption are generally calculated through environmental footprints, often pressure-based [14]. Examples include the carbon footprint [15,16], water footprint [17], land footprint [18], and material footprint [19]. All these indicators take a consumption-based approach, i.e., they consider the full life cycle of products and allocate impacts to the final consumer [14]. Life cycle assessment is one of the most widely used tools to assess household consumption's environmental impacts. In this sense, life cycle thinking and assessment have emerged as crucial approaches to pave the way towards sustainable consumption and production [14]. Several studies implement top-down methodologies to make a general assessment of the impacts of household consumption, such as the environmentally extended input-output model (EIO-LCA) [20], environmentally extended, multi-regional input-output (EE-MRIO) tables [14], among other combinations of LCA and input-output analysis. Alongside this, regional and national statistics and censuses have been widely used to model household consumption [21-23].

Top-down methods have the advantage of providing a coherent framework for the allocation of environmental burdens and resource consumption generated by macro-level economic systems. However, they lack product-level detail [14] and do not allow for site-specific analyses associated with households' socio-economic level and geographical location at the local level. On the other hand, other studies follow a bottom-up approach, based on the LCA of representative products, which are then up-scaled to overall consumption [24]. At the bottom-up level, it is possible to analyze specific geographical locations. Azimi et al. [25] through a survey questionnaire, examined the social impacts of the life cycle of the city of Kabul in Afghanistan. With the ultimate aim of supporting e-waste management in Vietnam [26], 1003 households in Hanoi and Hochiminh's urban areas, the two biggest cities in Vietnam, were surveyed. Leray et al. [27] conducted research based on a pilot survey conducted in the city of Bangalore, India. The study considered six households whose socio-economic status was representative of India's new urban middle classes. The results revealed a complex system of interactions between food supply, storage and management practices, and socio-cultural norms. In general, most bottom-up studies identify households' metabolism and their consumption practices, revealing the types of consumption and the patterns and behaviors that generate them. They also commonly propose actions for environmental policies applicable to urban areas. However, few studies have modeled future management scenarios in urban areas or assessed the effect these strategies might have on households' environmental impacts. 
This study was devised to assess households' life-cycle environmental impacts in Santiago, Chile, by household income level. In this way, the study sought to identify environmental hotspots and model future management scenarios associated with environmental policies. From the research analysis approach, it was possible to establish the main environmental benefits and adverse effects of decision-making, both those associated at the household level and those applicable at the national or urban level, through public policies.

\section{Materials and Methods}

\subsection{Goal and Scope}

The objective of this study was to assess the environmental impacts of households in the city of Santiago, Chile, associated with different levels of household income. For this purpose, the life cycle assessment methodology was applied according to the requirements established by the ISO 14,040 standard [28]. The functional unit (FU), defined as the quantified performance of a system for use as a reference unit [29], was 1 inhabitant/year, which represents the consumption of a single individual in one year $[11,23]$. The study's scope considered a cradle-to-grave approach, i.e., from the extraction of raw materials to the end of a product's life. In this sense, the product system analyzed the extraction of raw materials and fossil fuels, food production and processing, energy production, transport, waste management and disposal, drinking water production and distribution, domestic wastewater collection and treatment. Figure 1 presents the product system used to carry out the household life cycle assessment.



Figure 1. Product system used for the life cycle analysis of a household. T: transport, D: distribution.

\subsection{Life Cycle Inventory}

This study used a bottom-up methodology by conducting 300 household surveys in the city of Santiago. This information was complemented with secondary data from scientific articles, commercial databases, and national statistics. The surveys were conducted in three districts of Santiago with different socioeconomic characteristics. The selected districts were Providencia, Macul, and Pedro Aguirre Cerda, representing high, medium, and low socioeconomic levels, respectively. In each district, 100 randomly distributed surveys were conducted, which ensured a sample with different socioeconomic levels in Santiago. To obtain the sample, we used a shape of the urban property division for each district, which was obtained from the Chilean Internal Revenue Service [30]. The urban 
properties associated with a property roll number were selected randomly and then joined and distributed spatially through the ArcGIS 10.3 program. From this, a sample was generated and distributed throughout all macro sectors of Santiago.

The survey included 10 items and 63 questions, which were asked in the field using QuestionPro software. The items considered were: respondent and family group profile, household income, conditions and habitability, fuel consumption, household solid waste, environmental aspects, green areas, public transport, health system, and food. In the case of food, the information included in the Chilean Ministry of Social Development's basic family basket was considered. The basic basket considers a threshold of 2000 average daily calories per person and was based on Chile's VII Family Budget Survey [31]. In this sense, the categories included meats (beef, poultry and pork), fruits, vegetables, legumes, dairy products (yogurt, cheese, milk and butter, margarine), processed vegetable products (bread, flour, rice, oil, sugar, tea and coffee) and eggs. For the consumption of water, electricity, and natural gas, utility bills that contained the last 12 months' consumption were requested.

Electricity was modeled using SimaPro 9.1 software, considering the National Electricity System (SEN) matrix for 2019, according to Muñoz et al. [32]. The SEN generation for 2019 was $36.8 \%$ coal, $26.9 \%$ hydroelectric, $18.3 \%$ natural gas, $8.2 \%$ photovoltaic, $6.2 \%$ wind, $2.4 \%$ biomass, $0.8 \%$ oil and $0.4 \%$ geothermal [33].

Public transport (bus and subway) is considered the time elapsed from home to destination (work, school, university, shopping, among others). For the transformation of minutes to kilometers traveled, average speeds were used, $45 \mathrm{~km} / \mathrm{h}$ for the subway [34] and $14.3 \mathrm{~km} / \mathrm{h}$ for buses [35]. The survey considered the average monthly consumption of gasoline and diesel fuel used by vehicles in each household for private transport.

Through SimaPro, the Ecoinvent 3.6 databases for vehicles and buses were used. From the same database, food, fuel, water, landfill, wastewater treatment, and subway systems were adapted to local conditions. Due to the non-existence of life cycle approach databases in Chile, national statistics and scientific research associated with life cycle analysis in Chile were used to adapt international databases. For example, for domestic wastewater treatment, information was used from [36], electricity [37], agricultural products [38-40] and landfill [41].

The collected and modeled data were allocated among the inhabitants of each household. Households were then classified according to per capita income level. The classification considered five economic quintiles, according to the per capita income ranges presented in Table 1.

Table 1. Distribution of Santiago inhabitants in quintiles according to household per capita income level (adapted from [42]).

\begin{tabular}{cccc}
\hline Quintile & From (USD) & To (USD) & Households Share (\%) \\
\hline I & 0 & 120 & 5.8 \\
II & 120 & 210 & 10.1 \\
III & 210 & 315 & 14.2 \\
IV & 315 & 560 & 20.3 \\
V & 560 & - & 49.6 \\
\hline
\end{tabular}

\subsection{Environmental Impact Assessment}

The impact assessment was carried out using SimaPro 9.1 software, selecting the Recipe MidPoint $(\mathrm{H})$ assessment method. The impact categories analyzed were global warming ( $\mathrm{kg} \mathrm{CO}_{2} \mathrm{eq}$ ), fine particulate matter formation ( $\mathrm{kg}$ PM eq), land acidification ( $\mathrm{kg}$ $\left.\mathrm{SO}_{2} \mathrm{eq}\right)$, freshwater eutrophication (kg P eq), freshwater ecotoxicity (kg 1.4 DCB), mineral resource scarcity (kg Cu eq), and fossil resource scarcity (kg oil eq). These categories were selected as they represent the most commonly used categories within national research and city- and household-specific literature.

From contribution analysis, the main environmental hotspots of the household were identified. Hotspot identification implies identifying elements within the system that con- 
tribute to a specific impact category [32]. In this sense, identifying an environmental hotspot allows for identification of opportunities to improve the environmental performance of activities, products, or services of organizations.

\subsection{Environmental Management Scenarios}

Two scenarios were analyzed to assess the effects of public policies in force in Chile with a time horizon of implementation to 2050. The first is associated with the National Electromobility Policy of the Chilean Ministry of Energy [43]. This policy aims for $100 \%$ of the public transport fleet and $40 \%$ of private vehicles to be electric by 2050, representing Scenario 2. The second is associated with the 2050 energy policy of the Chilean Ministry of Energy [44], which affects all subsystems of the household product system under study. This policy aims to increase energy production based on renewable sources, reduce the use of fossil fuels, and minimize the national energy matrix's environmental impacts. Thus, Scenario 2 modelled the 2050 matrix, which considers the following: $48.86 \%$ photovoltaic, $27.39 \%$ wind, $21.02 \%$ hydroelectric, $1.78 \%$ natural gas, $0.66 \%$ biomass, $0.16 \%$ geothermal, $0.09 \%$ oil, and $0.04 \%$ coal. A third scenario considered implementing the National Electromobility Policy together with the electricity mix change in 2050. Based on the policies, the analyses considered the following scenarios:

Scenario 0: Current situation without the implementation of the policies.

Scenario 1: Public transport 100\% electric and private transport $40 \%$, electricity grid 2019.

Scenario 2: Implementation of the 2050 electricity matrix.

Scenario 3: Public transport $100 \%$ electric, private transport $40 \%$, and electricity grid 2050.

\section{Results and Discussion}

\subsection{Life Cycle Inventory}

Inventory is a fundamental stage in a life cycle assessment, especially when data are collected in the field. These so-called foreground data are generally scarce in household and city life cycle studies as they mainly use top-down information from national statistics. Table 2 presents a summary of the main foreground data collected through household surveys. In the table, it is possible to see that most of the flows associated with each sub-system increase as household income increases.

Table 2. Summary of life cycle inventory data of the foreground associated with the functional unit.

\begin{tabular}{|c|c|c|c|c|c|c|}
\hline \multirow{2}{*}{ Subsystem } & \multirow{2}{*}{ Unit } & \multicolumn{5}{|c|}{ Household Income Quintile } \\
\hline & & I & II & III & IV & $\mathbf{V}$ \\
\hline Water & $\mathrm{m}^{3} /$ inh/year & 55.4 & 68.9 & 66.0 & 83.4 & 90.5 \\
\hline Fruits & $\mathrm{kg} /$ inh/year & 28.4 & 52.1 & 57.9 & 52.8 & 54.1 \\
\hline Vegetables & $\mathrm{kg} /$ inh/year & 86.0 & 140.1 & 142.0 & 140.4 & 119.4 \\
\hline Legumes & $\mathrm{kg} /$ inh/year & 8.3 & 17.0 & 18.2 & 19.2 & 14.2 \\
\hline Processed products & $\mathrm{kg} /$ inh/year & 100.4 & 140.7 & 139.8 & 122.4 & 101.2 \\
\hline Dairy products & $\mathrm{kg} /$ inh/year & 21.9 & 40.6 & 40.9 & 41.9 & 50.6 \\
\hline Pork & $\mathrm{kg} /$ inh/year & 2.1 & 6.6 & 10.1 & 6.9 & 4.6 \\
\hline Chicken & $\mathrm{kg} /$ inh/year & 9.6 & 13.8 & 14.8 & 20.1 & 15.8 \\
\hline Beef & $\mathrm{kg} /$ inh/year & 7.2 & 10.3 & 12.8 & 15.8 & 15.7 \\
\hline Municipal solid waste & $\mathrm{kg} /$ inh/year & 153.7 & 295.7 & 218.8 & 369.9 & 637.2 \\
\hline Electricity & kWh/inh/year & 569.7 & 778.0 & 753.2 & 861.7 & 1204.5 \\
\hline Liquefied petroleum gas & kWh/inh/year & 7500 & 11,389 & 10,278 & 16,667 & 7222 \\
\hline Kerosene & kWh/inh/year & 277.8 & 527.8 & 305.6 & 611.1 & 555.6 \\
\hline Natural gas & kWh/inh/year & 55.6 & 277.8 & 1944.4 & 1388.9 & 3333.3 \\
\hline Gasoline & kWh/inh/year & 6111 & 6389 & 4722 & 10,556 & 21,389 \\
\hline Diesel fuel & kWh/inh/year & 0 & 1944.4 & 2222.2 & 3333.3 & 5277.8 \\
\hline Wastewater & $\mathrm{m}^{3} /$ inh/year & 44.3 & 55.1 & 52.8 & 66.7 & 72.4 \\
\hline
\end{tabular}


In water, the Chilean Superintendency of Sanitary Services reported a national consumption value of $162.5 \mathrm{~L}$ per inhabitant per day (L/inh/d) for the year 2019 [45]. In this study, the value varies from $153.5 \mathrm{~L} / \mathrm{inh} / \mathrm{d}$ in the first quintile to 247.9 in the fifth quintile. An average consumption of $81.4 \mathrm{~m}^{3} /$ inh/year was determined from the sample, which is higher than those reported in Spanish cities, ranging from $39.1 \mathrm{~m}^{3} /$ inh/year to $62.9 \mathrm{~m}^{3} /$ inh/year [46]. Household solid waste generation also increased with increasing income levels. This environmental aspect increased by over $300 \%$ from quintile 1 to quintile 5. The average generation for Santiago obtained in the study was $461 \mathrm{~kg} /$ inh/year, which is higher than the $445 \mathrm{~kg} / \mathrm{inh} /$ year reported by the Chilean Undersecretariat of Regional and Administrative Development for 2017 [47]. Another notable element in the inventory is related to energy consumption, which increased as household income levels rose. The most considerable differences are observed for natural gas, followed by gasoline, diesel fuel, and electricity. In food consumption, eating patterns do not show a clear trend according to household income level. Nonetheless, the first quintile has the lowest consumption.

\subsection{Influence of Household Income Level on Environmental Impacts}

Several studies have assessed the environmental impacts of households through the LCA methodology. However, the studies have not examined household income level and how this influences environmental impacts. As Figure 2 shows, the higher the household income level (quintile 5), the higher the environmental impacts. This trend is present in all the impact categories assessed, with freshwater ecotoxicity standing out with a $61 \%$ difference between the first and fifth quintile.

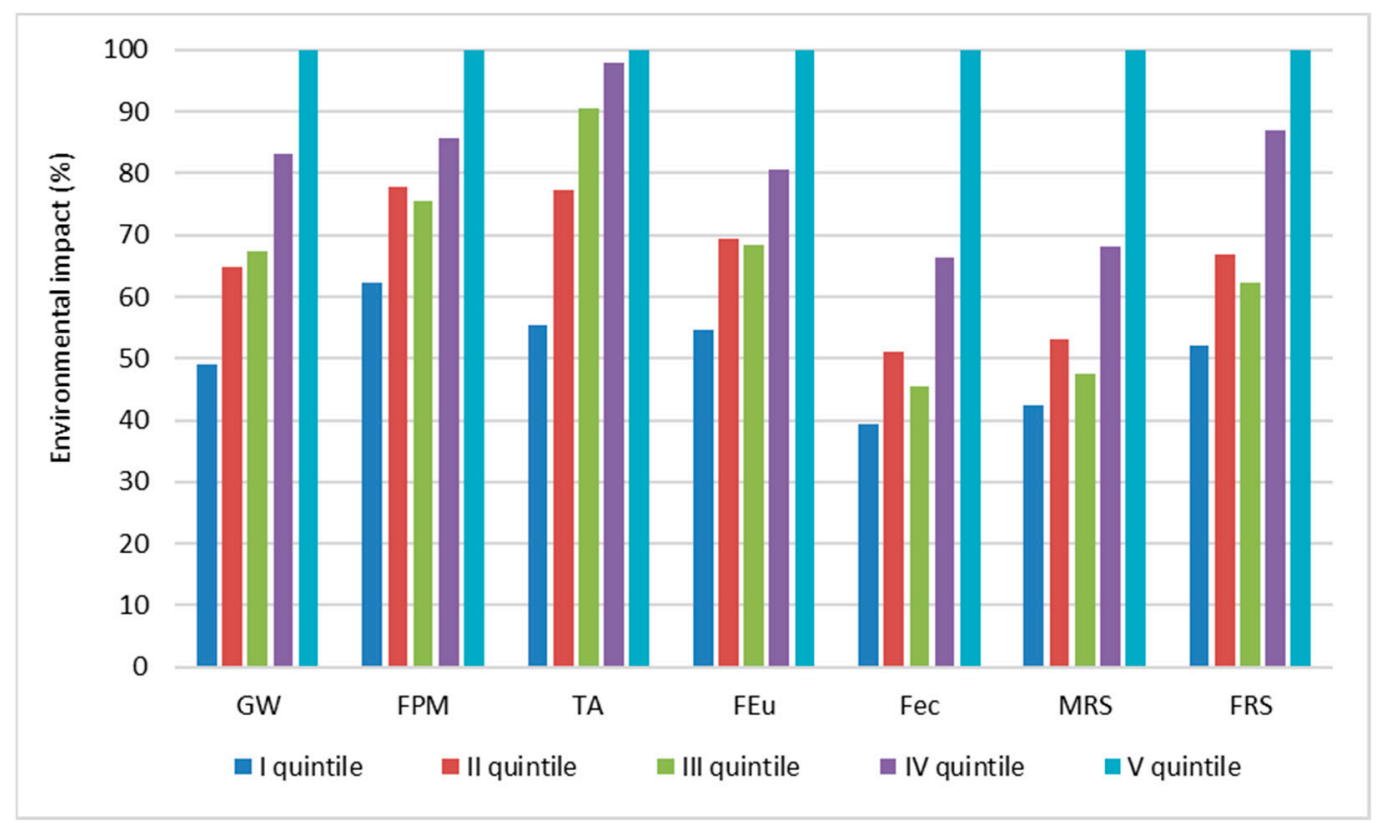

Figure 2. Comparison of environmental impacts of households at different income levels. GW: Global warming, FPM: Fine particulate matter formation, TA: Terrestrial acidification, FEu: Freshwater eutrophication, FEc: Freshwater ecotoxicity, MRS: Mineral resource scarcity, FRS: Fossil resource scarcity.

In global warming, the average impact of a household in Santiago was $3.44 \mathrm{t} \mathrm{CO}_{2}$ eq/inh/year, with the first quintile having a value of $1.98 \mathrm{t} \mathrm{CO}_{2} \mathrm{eq} / \mathrm{inh} /$ year and the fifth quintile $4.04 \mathrm{t} \mathrm{CO}_{2} \mathrm{eq} / \mathrm{inh} /$ year. Similar values have been reported in Spanish cities, reaching $2.4 \mathrm{t} \mathrm{CO}_{2} \mathrm{eq} / \mathrm{inh} /$ year in Barcelona, $4.2 \mathrm{t} \mathrm{CO}_{2} \mathrm{eq} / \mathrm{inh} /$ year in Madrid and Seville, and $4.3 \mathrm{t} \mathrm{CO}_{2} \mathrm{eq} / \mathrm{inh} /$ year in Valencia [46]. In this category, the fifth quintile inhabitants double the environmental impacts of the first quintile, which is mainly due to fuel consumption patterns associated with transport. According to Chile's nationally determined contributions (NDC), the carbon footprint of an average Chilean is $4.7 \mathrm{t} \mathrm{CO}_{2}$ 
eq/inh/year [48]. In this sense, the metabolism of households in Santiago accounts for $73.4 \%$ of the global warming impacts of an average Chilean inhabitant. This percentage varies from $41.9 \%$ in households in the first quintile to $85.6 \%$ in households in the fifth quintile. Similar values have been reported by Ivanova et al., (65\%) [49] and Hertwich and Peters (72\%) [15]. Both authors indicate that global greenhouse gas (GHG) emissions are mainly influenced by household consumption. In this sense, the carbon footprint is strongly correlated with per capita consumption expenditure [15]. That is, the higher the household consumption, the higher the GHG emissions. The latter is equivalent to the level of household income.

In Table 3, it is possible to observe the values of the impact category indicators for all the quintiles and categories evaluated. An average Santiago inhabitant generates environmental impacts of $11.3 \mathrm{~kg}$ PM2.5 eq/inh/year, $22.5 \mathrm{~kg} \mathrm{SO}$ eq/inh/year, $10.3 \mathrm{~kg}$ $\mathrm{P}$ eq/inh/year, $92.9 \mathrm{~kg}$ 1,4-DCB eq/inh/year, $7.38 \mathrm{~kg} \mathrm{Cu} \mathrm{eq/inh/year,} \mathrm{and} 710 \mathrm{~kg}$ oil $\mathrm{eq} /$ inh/year. The average values are strongly influenced by the fifth and fourth quintiles, representing $20.3 \%$ and $49.6 \%$ of households, respectively. Similar results were obtained by García-Guaiti et al. [23] for terrestrial acidification ( $45 \mathrm{~kg} \mathrm{SO}_{2} \mathrm{eq} / \mathrm{inh} /$ year) and freshwater eutrophication (1.1 kg P eq/inh/year) for an average inhabitant of Santiago de Compostela in Spain. For the fine particulate matter formation category, the value obtained for a sample from Spain was $6 \mathrm{~kg}$ PM2.5 eq/inh/year [46], which is lower than the values obtained in this study. This result may be influenced by the composition of the Spanish electricity matrix where renewable energies reach values close to $40 \%$, while coal and combined cycle represent $13.5 \%$ and $10 \%$, respectively. In Chile, coal-based power generation represents $36.8 \%$, which implies higher impacts on the particulate matter formation impact category.

Table 3. Household environmental impact assessment by income level (quintile).

\begin{tabular}{|c|c|c|c|c|c|c|}
\hline \multirow{2}{*}{ Impact Category } & \multirow{2}{*}{ Unit } & \multicolumn{5}{|c|}{ Household Income Quintile } \\
\hline & & I & II & III & IV & $\mathbf{V}$ \\
\hline Global warming & $\mathrm{kgCO}_{2} \mathrm{eq}$ & 1980 & 2616 & 2726 & 3363 & 4038 \\
\hline Fine particulate matter formation & kg PM2.5 eq & 7.9 & 9.9 & 9.6 & 10.9 & 12.7 \\
\hline Terrestrial acidification & $\mathrm{kg} \mathrm{SO}_{2} \mathrm{eq}$ & 13.3 & 18.6 & 21.8 & 23.6 & 24.1 \\
\hline Freshwater eutrophication & $\mathrm{kg} P$ eq & 0.65 & 0.83 & 0.82 & 0.97 & 1.20 \\
\hline Freshwater ecotoxicity & kg 1,4-DCB & 47.5 & 61.7 & 54.8 & 80.0 & 120.7 \\
\hline Mineral resource scarcity & $\mathrm{kg} \mathrm{Cu} \mathrm{eq}$ & 4.0 & 5.0 & 4.5 & 6.4 & 9.5 \\
\hline Fossil resource scarcity & $\mathrm{kg}$ oil eq & 431 & 553 & 515 & 719 & 828 \\
\hline
\end{tabular}

\subsection{Environmental Hotspot Analysis}

Based on the contribution analysis, it was possible to identify the main household environmental hotspots. As shown in Figure 3, food consumption is the main hotspot, responsible for $33 \%$ of the environmental impacts on global warming, $69 \%$ on terrestrial acidification and $29 \%$ on freshwater eutrophication. In all three impact categories, food is the leading environmental hotspot. In the remaining categories, food accounts for between $11 \%$ and $21 \%$ of the impacts. According to Hertwich and Peters [15], nutrition is the most important consumption category, with food accounting for nearly $20 \%$ of GHG emissions. The second most important source is private transport, generating the highest impacts in the categories of freshwater ecotoxicity-with 59\%; mineral resource scarcity-with $55 \%$; fossil resource scarcity-with $35 \%$. It is also the second most important source of global warming-with $22 \%$. The third source of environmental importance is electricity consumption. This flow generates the highest environmental load in the category of fine particulate matter formation, accounting for $45 \%$ of the environmental impact. Other impact categories strongly influenced by electricity are freshwater eutrophication and freshwater ecotoxicity, representing the second most important environmental source with $28 \%$ and $14 \%$ of the impacts, respectively. 


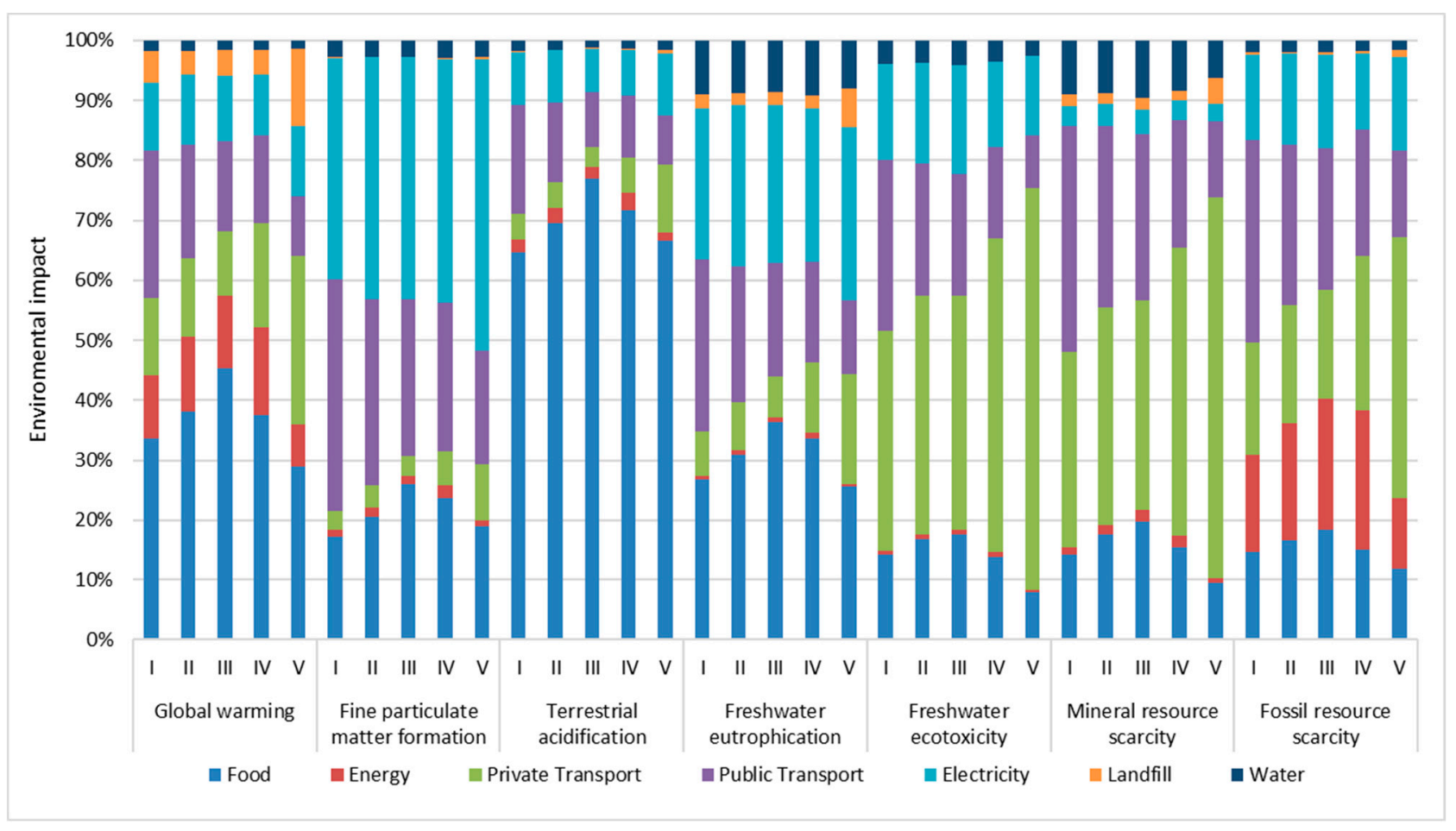

Figure 3. Household environmental contribution analysis by income level (quintile).

In Figure 3, it is possible to observe an inverse relationship between private car use and public transport, which influences the environmental impacts of each quintile. In this sense, the contribution to private transport's environmental impact rises with household income increase, while that of public transport increases with a decrease in household income. There is no clear trend regarding the contribution to food's environmental impacts, which is associated with the absence of trends in food consumption according to each quintile.

Within the food group, meat consumption was found to be the primary environmental source in the impact categories of global warming (50-60\%), fine particulate matter formation (52-65\%), terrestrial acidification (60-71\%), and freshwater eutrophication (51-63\%). Concurrently, processed animal products account for between $15 \%$ and $20 \%$ of the impacts in the same categories, reflecting animal foods' contribution in all four impact categories. In the impact categories of freshwater ecotoxicity, mineral resources scarcity, and fossil resources scarcity, foods of plant origin (vegetables, processed vegetables, and fruits) are the main environmental sources, accounting for between $41 \%$ and $69 \%$ of the impacts. In this group, vegetables are the primary source, reaching up to $30 \%$ of freshwater ecotoxicity impacts, $37 \%$ in mineral resource scarcity, and 23\% in fossil resource scarcity.

\subsection{Scenarios Analysis}

Based on Santiago's modeling, the implementation of two public policies in Chile, projected to 2050, were analyzed. The first (Scenario 1), which is being applied to public transport, projects having $100 \%$ of public transport and $40 \%$ of private vehicles being electric by 2050 [43]. The second (Scenario 2), associated with energy policy, aims to have at least $70 \%$ of the total electricity generation from renewable energy by the same year [44]. Figure 1 presents the modeling of the scenarios mentioned above, the current scenario (Scenario 0), and a scenario that considers the implementation and fulfillment of both policies. It can be seen that the categories of global warming impact, freshwater acidification, and fossil resource scarcity show similar trends in all scenarios. In freshwater acidification and fossil resource, the combination of both policies in 2050 would reduce environmental impacts by $18 \%$ and $52 \%$, respectively. In global warming, the reduction 
would be $34 \%$, which would translate to a carbon footprint to decrease from $3.44 \mathrm{~kg} \mathrm{CO}_{2}$ eq/inh/year to $2.3 \mathrm{~kg} \mathrm{CO}_{2} \mathrm{eq} /$ inh/year.

Furthermore, in the three impact categories mentioned above, a synergistic effect is observed when both policies are applied together. The reason for this is that, in electromobility Scenario 1, transport decreases the consumption of fossil fuels (gasoline and diesel) and increases electricity consumption. However, the change of energy generates a decrease in greenhouse gas emissions. In Scenario 2, only the consumption of fossil fuels in the energy matrix decreases, without affecting transport emissions. In Scenario 3, in addition to applying both reductions (Scenarios 1 and 2), the minimization of fossil fuels associated with electricity consumption in public and private transport is added, a factor not present in Scenarios 1 and 2. Similar results were obtained by Nissinen et al. [50] in their study on the environmental effects of combining policy instruments. They concluded that when a set of instruments is examined as a whole, as combinations of policy instruments or 'policy packages,' the synergies between measures can be reinforced, and hence overall effectiveness can be improved.

In the category of fine particulate matter formation, it is observed that the increase in the number of electric vehicles leads to an increase in environmental impacts. Although electric vehicles generate practically zero local emissions of particulate matter, these emissions are generated in electricity generation plants. In this sense, a vehicle loaded with electricity from a coal power plant causes by far the highest burdens in the fine particular matter formation category [51]. In Chile's case, coal is the main contributor to the electricity matrix with $36.8 \%$, which generates the highest environmental impacts on particulate matter formation in Scenario 2. For this reason, the increase in the electric car fleet in Santiago will have adverse effects on the fine particulate matter formation and freshwater eutrophication impact categories under the current electricity scenario in Chile. However, if electromobility of transport is implemented in conjunction with the electricity matrix's decarbonization (Scenario 3), environmental impacts are significantly reduced. As shown in Figure 4, impacts in the fine particulate matter formation category could be reduced by up to $72 \%$, which implies the need to move forward in conjunction with both policies.

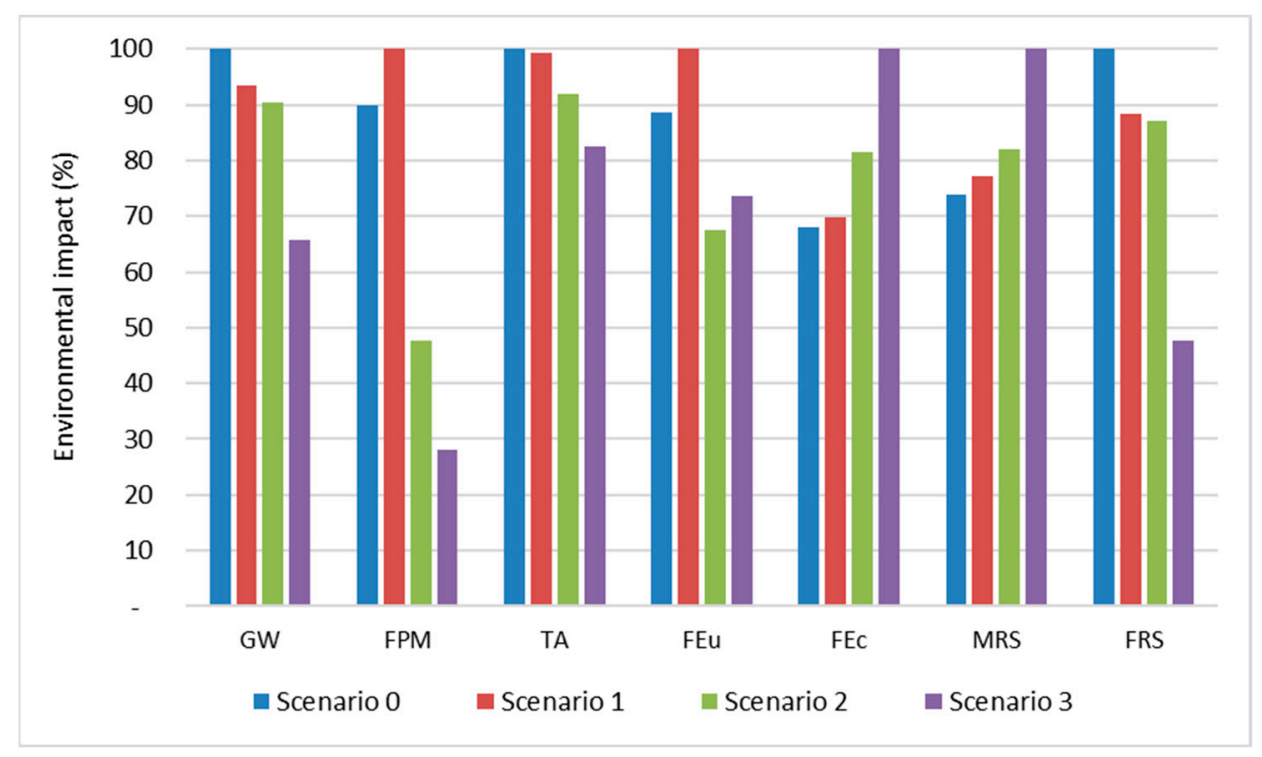

Figure 4. Comparative analysis of household scenarios in Santiago. Scenario 0: current situation; Scenario 1: $100 \%$ electric public transport, $40 \%$ electric private transport, and electricity grid 2019; Scenario 2: electricity matrix 2050; Scenario 3: Public transport $100 \%$ electric, private transport 40\%, and electricity grid 2050. GW: Global warming, FPM: Fine particulate matter formation, TA: Terrestrial acidification, FEu: Freshwater eutrophication, FEc: Freshwater ecotoxicity, MRS: Mineral resource scarcity, FRS: Fossil resource scarcity. 
The scenario analysis shows that the impact categories of freshwater ecotoxicity and mineral resource scarcity increase with the application of both policies, showing a negative synergistic effect on environmental impacts. In the case of freshwater ecotoxicity, the main environmental hotspot in Scenario 1 is electricity consumption. In this sense, the increase in electricity consumption due to the vehicle fleet's change is reflected in the increase of the impact. It is important to note that the main hotspots for freshwater ecotoxicity in electricity are associated with hard coal production with about $48 \%$, followed by photovoltaic and wind power production with $22 \%$ and $18 \%$, respectively. These last two values are high considering that photovoltaic power currently accounts for $8.2 \%$, and wind for $6.2 \%$, of total energy production. As shown in Figure 1, the increase to $48.86 \%$ of photovoltaic and $27.39 \%$ of wind by 2050 will significantly increase the impacts on freshwater ecotoxicity. Thus, the increase in impacts from the change in the electricity mix, plus the increase in electricity consumption by the electric vehicle fleet, results in the negative effects on freshwater ecotoxicity in Scenario 3. In the case of the mineral resource scarcity category, a similar phenomenon occurs for freshwater ecotoxicity. In this case, future scenarios are strongly influenced by the increase in photovoltaic and wind energy and by the increase in electric cars and electric vehicle consumption. In this category, iron, nickel, aluminum, and copper are the substances that contribute to the highest environmental load. In the case of electric cars, the consumption of iron (21\%), nickel (11\%), copper $(6 \%)$, and lithium $(6 \%)$ for their production and batteries are the main environmental sources. In the 2050 electricity matrix, the consumption of iron (14\%), aluminum (12\%), copper (9\%), and nickel (8\%), mainly associated with photovoltaic panels, are primarily responsible for the impact on the scarcity of mineral resources.

\section{Conclusions}

From this study, it could be determined that the level of household income influences environmental impacts. In this sense, the higher the income level, the more significant the environmental impacts. Aspects associated with food, use of private vehicles, public transport, and electricity were determined to be the main environmental sources of households, and therefore, elements that should be considered in public policies applied at the urban level.

From the analysis of two long-term public policies planned in Chile, it was concluded that electromobility in public and private transport would have positive environmental effects on the categories of global warming, terrestrial acidification, and fossil fuel scarcity. However, it will generate adverse effects on fine particular matter formation, freshwater eutrophication, freshwater ecotoxicity, and mineral resource scarcity. For the policy associated with the decarbonization of the electricity grid, environmental impacts are reduced in most of the categories assessed, except for the categories of freshwater ecotoxicity and mineral resources scarcity. These two impact categories increase with each policy's implementation, with a negative synergistic effect observed when both are met. On the contrary, achieving the goals of electromobility and increasing the share of renewable energy in the electricity mix by 2050 generates a positive synergistic effect on the household's environmental impacts. In this sense, the application of both policies will reduce the impacts on global warming, fine particular matter formation, terrestrial acidification, and fossil fuel scarcity. Both negative and positive effects are vital for decision-making and, therefore, should be considered in consumer policies and policymaking.

Author Contributions: Formal analysis, E.M.; Funding acquisition, E.M.; Investigation, C.L.-E., E.G.-R., I.F.-A. and E.M.; Methodology, C.L.-E. and E.M.; Project administration, C.L.-E.; Software, C.L.-E. and E.M.; Supervision, E.M.; Validation, E.M.; Writing - original draft, E.M.; Writing review \& editing, E.G.-R. and I.F.-A. All authors have read and agreed to the published version of the manuscript.

Funding: This research was funded by "ANID/CONICYT FONDECYT Iniciación 11170992" of Chile. 
Institutional Review Board Statement: The study was conducted according to the guidelines of the Declaration of Helsinki, and approved by Bioethics Committee of Universidad Andrés Bello, protocol code 029/2017 of 27 December 2017.

Informed Consent Statement: Informed consent was obtained from all subjects involved in the study.

Data Availability Statement: The data presented in this study are available on request from the corresponding author. The data are not publicly available due to privacy restrictions according to protocol code $029 / 2017$

Conflicts of Interest: The authors declare no conflict of interest.

\section{References}

1. Muñoz, E.; Navia, R. Circular economy in urban systems: How to measure the impact? Waste Manag. Res. 2021, 39, 197-198. [CrossRef]

2. Romero-Lankao, P.; Gnatz, D.M. Conceptualizing urban water security in an urbanizing world. Curr. Opin. Environ. Sustain. 2016, 21, 45-51. [CrossRef]

3. Zinatizadeh, S.; Monavari, S.M.; Azmi, A.; Sobhanardakani, S. Evaluation and prediction of sustainability of urban areas: A case study for Kermanshah city, Iran. Cities 2017, 66, 1-9. [CrossRef]

4. Nations, U. World Urbanization Prospects: The 2018 Revision; United Nations: New York, NY, USA, 2019 ; Volume 12.

5. Hertwich, E.G. Life cycle approaches to sustainable consumption: A critical review. Environ. Sci. Technol. 2005, 39, 4673-4684. [CrossRef] [PubMed]

6. United Nations. The System of National Accounts 2018; United Nations: New York, NY, USA, 2009.

7. Di Donato, M.; Lomas, P.L.; Carpintero, Ó. Metabolism and environmental impacts of household consumption: A review on the assessment, methodology, and drivers. J. Ind. Ecol. 2015, 19, 904-916. [CrossRef]

8. Tukker, A. Identifying priorities for environmental product policy. J. Ind. Ecol. 2006, 10, 1-4. [CrossRef]

9. Caeiro, S.; Ramos, T.B.; Huisingh, D. Procedures and criteria to develop and evaluate household sustainable consumption indicators. J. Clean. Prod. 2012, 27, 72-91. [CrossRef]

10. Froemelt, A.; Dürrenmatt, D.J.; Hellweg, S. Using Data Mining to Assess Environmental Impacts of Household Consumption Behaviors. Environ. Sci. Technol. 2018, 52, 8467-8478. [CrossRef]

11. Matuštík, J.; Kočí, V. Environmental impact of personal consumption from life cycle perspective-A Czech Republic case study. Sci. Total Environ. 2019, 646, 177-186. [CrossRef]

12. Newton, P.; Meyer, D. The determinants of urban resource consumption. Environ. Behav. 2012, 44, 107-135. [CrossRef]

13. Kalbar, P.P.; Birkved, M.; Hauschild, M.; Kabins, S.; Nygaard, S.E. Environmental impact of urban consumption patterns: Drivers and focus points. Resour. Conserv. Recycl. 2018, 137, 260-269. [CrossRef]

14. Castellani, V.; Beylot, A.; Sala, S. Environmental impacts of household consumption in Europe: Comparing process-based LCA and environmentally extended input-output analysis. J. Clean. Prod. 2019, 240, 117966. [CrossRef]

15. Hertwich, E.G.; Peters, G.P. Carbon footprint of nations: A global, trade-linked analysis. Environ. Sci. Technol. 2009, 43, 6414-6420. [CrossRef]

16. Davis, S.J.; Caldeira, K. Consumption-based accounting of CO 2 emissions. Proc. Natl. Acad. Sci. USA 2010, 107, 5687-5692. [CrossRef]

17. Hoekstra, A.Y.; Mekonnen, M.M. The water footprint of humanity. Proc. Natl. Acad. Sci. USA 2012, 109, 3232-3237. [CrossRef] [PubMed]

18. Bruckner, M.; Fischer, G.; Tramberend, S.; Giljum, S. Measuring telecouplings in the global land system: A review and comparative evaluation of land footprint accounting methods. Ecol. Econ. 2015, 114, 11-21. [CrossRef]

19. Lausselet, C.; Ellingsen, L.A.W.; Strømman, A.H.; Brattebø, H. A life-cycle assessment model for zero emission neighborhoods. J. Ind. Ecol. 2020, 24, 500-516. [CrossRef]

20. Kim, D.; Parajuli, R.; Thoma, G.J. Life cycle assessment of dietary patterns in the United States: A full food supply chain perspective. Sustainability 2020, 12, 1586. [CrossRef]

21. Ng, K.S.; To, L.S. A systems thinking approach to stimulating and enhancing resource efficiency and circularity in households. J. Clean. Prod. 2020, 275, 123038. [CrossRef]

22. Matuštík, J.; Kočí, V. A comparative life cycle assessment of electronic retail of household products. Sustainability 2020, $12,4604$. [CrossRef]

23. García-Guaiti, F.; González-García, S.; Villanueva-Rey, P.; Moreira, M.T.; Feijoo, G. Integrating Urban Metabolism, Material Flow Analysis and Life Cycle Assessment in the environmental evaluation of Santiago de Compostela. Sustain. Cities Soc. 2018, 40, 569-580. [CrossRef]

24. Sala, S.; Castellani, V. The consumer footprint: Monitoring sustainable development goal 12 with process-based life cycle assessment. J. Clean. Prod. 2019, 240, 118050. [CrossRef] [PubMed]

25. Azimi, A.N.; Dente, S.M.R.; Hashimoto, S. Social life-cycle assessment of householdwaste management system in Kabul city. Sustainability 2020, 12, 3217. [CrossRef] 
26. Tran, H.P.; Schaubroeck, T.; Nguyen, D.Q.; Ha, V.H.; Huynh, T.H.; Dewulf, J. Material flow analysis for management of waste TVs from households in urban areas of Vietnam. Resour. Conserv. Recycl. 2018, 139, 78-89. [CrossRef]

27. Leray, L.; Sahakian, M.; Erkman, S. Understanding household food metabolism: Relating micro-level material flow analysis to consumption practices. J. Clean. Prod. 2016, 125, 44-55. [CrossRef]

28. ISO. Environmental Management_Life Cycle Assessment_Principles and Framework; ISO: Geneva, Switzerland, 2006.

29. ISO. Environmental Management_Life Cycle Assessment_Requirements and Guidelines; ISO: Geneva, Switzerland, 2006.

30. SII Cartografía Digital SII Mapas. Available online: https://www4.sii.cl/mapasui/internet/\#/contenido/index.html (accessed on 14 August 2018).

31. INE. Informe de Principales Resultados VIII Encuesta de Presupuestos Familiares (EPF); INE: Santiago, Chile, 2018.

32. Muñoz, E.; Curaqueo, G.; Cea, M.; Vera, L.; Navia, R. Environmental hotspots in the life cycle of a biochar-soil system. J. Clean. Prod. 2017, 158, 1-7. [CrossRef]

33. CNE. Anuario Estadístico de Energía 2019; CNE: Santiago, Chile, 2020.

34. Ministerio de Transportes y Telecomunicaciones, Informe de Evaluación Externa al Sistema de Transporte Público Remunerado de Pasajeros de la Provincia de Santiago y de las Comunas de San Bernardo y Puente Alto. Available online: http:/ / biblioteca. digital.gob.cl/handle/123456789/972 (accessed on 1 January 2021).

35. DTP. Mejoramiento y Actualización del Modelo de Asignación de viajes del Sistema Transantiago; DTP: Santiago, Chile, 2018.

36. Abello-Passteni, V.; Muñoz Alvear, E.; Lira, S.; Garrido-Ramírez, E. Evaluación de Eco-Eficiencia de Tecnologías de Tratamiento de Aguas Residuales Domésticas en Chile. Tecnología y Ciencias del Agua 2020, 11, 190-228. [CrossRef]

37. Gaete-Morales, C.; Gallego-Schmid, A.; Stamford, L.; Azapagic, A. Assessing the environmental sustainability of electricity generation in Chile. Sci. Total Environ. 2018, 636, 1155-1170. [CrossRef] [PubMed]

38. Montalba, R.; Vieli, L.; Spirito, F.; Muñoz, E. Environmental and productive performance of different blueberry (Vaccinium corymbosum L.) production regimes: Conventional, organic, and agroecological. Sci. Hortic. (Amsterdam) 2019, $256,108592$. [CrossRef]

39. Muñoz, E.; Navia, R.; Zaror, C.; Alfaro, M. Ammonia emissions from livestock production in chile: An inventory and uncertainty analysis. J. Soil Sci. Plant Nutr. 2016, 16, 60-75. [CrossRef]

40. Herrera, J.; Muñoz, E.; Montalba, R. Evaluation of two production methods of Chilean wheat by life cycle assessment (LCA). IDESIA 2012, 30, 101-110. [CrossRef]

41. Bezama, A.; Douglas, C.; Méndez, J.; Szarka, N.; Muñoz, E.; Navia, R.; Schock, S.; Konrad, O.; Ulloa, C. Life cycle comparison of waste-to-energy alternatives for municipal waste treatment in Chilean Patagonia. Waste Manag. Res. 2013, 31, 67-74. [CrossRef]

42. Gajardo, S. Pobreza y distribución del ingreso en la Región Metropolitana de Santiago: Resultados Encuesta CASEN 2015. Available online: https:/ / www.desarrollosocialyfamilia.gob.cl/storage/docs/DOCUMENTO_POBREZA_Y_DISTR_ING_RMS_ CASEN_2017.pdf (accessed on 1 January 2021).

43. Ministerio de Energía-Gobierno de Chile. Estrategia Nacional de Electromovilidad; Santiago, Chile. 2017. Available online: https://energia.gob.cl/sites/default/files/estrategia_electromovilidad-8dic-web.pdf (accessed on 1 January 2021).

44. Ministerio de Energía-Gobierno de Chile. Energía 2050-Política Energética de Chile; Santiago, Chile. 2015. Available online: https:/ / observatoriop10.cepal.org/es/instrumentos/politica-energetica-chile-energia-2050 (accessed on 1 January 2021).

45. Superintendencia de Servicios Sanitarios (SISS)—Gobierno de Chile. Informe de Gestión del Sector Sanitario; Santiago, Chile. 2019. Available online: https:/ / www.coursehero.com/file/75668465/Informe-de-gestion-sector-sanitario-SISS-2019pdf/ (accessed on 1 January 2021).

46. Gonzalez-Garcia, S.; Manteiga, R.; Moreira, M.T.; Feijoo, G. Assessing the sustainability of Spanish cities considering environmental and socio-economic indicators. J. Clean. Prod. 2018, 178, 599-610. [CrossRef]

47. SUBDERE—Gobierno de Chile. In Diagnostico de la Situación por Comuna y por Región en Materia de Residuos Sólidos Domiciliarios y Asimilables; Santiago, Chile; 2018. Available online: http://www.subdere.gov.cl/sites/default/files/4.1_diagnostico_introduccion_ agosto_2018.pdf (accessed on 1 January 2021).

48. Gobierno de Chile. Contribución Determinada a Nivel Nacional (NDC) de Chile; Santiago, Chile. 2020. Available online: https: //mma.gob.cl/wp-content/uploads/2019/10/Propuesta_actualizacion_NDC_Chile_2019.pdf (accessed on 1 January 2021).

49. Ivanova, D.; Stadler, K.; Steen-Olsen, K.; Wood, R.; Vita, G.; Tukker, A.; Hertwich, E.G. Environmental Impact Assessment of Household Consumption. J. Ind. Ecol. 2016, 20, 526-536. [CrossRef]

50. Nissinen, A.; Heiskanen, E.; Perrels, A.; Berghäll, E.; Liesimaa, V.; Mattinen, M.K. Combinations of policy instruments to decrease the climate impacts of housing, passenger transport and food in Finland. J. Clean. Prod. 2015, 107, 455-466. [CrossRef]

51. Bauer, C.; Hofer, J.; Althaus, H.J.; Del Duce, A.; Simons, A. The environmental performance of current and future passenger vehicles: Life Cycle Assessment based on a novel scenario analysis framework. Appl. Energy 2015, 157, 871-883. [CrossRef] 